September 1971 Directory

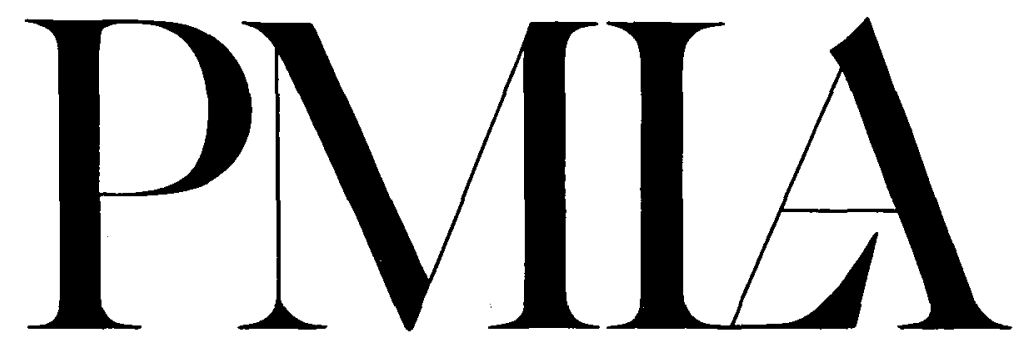

\title{
Publications of the
}

Modern Language Association of America

Volume 86

Number 4

PUBLISHED SIX TIMES A YEAR BY THE ASSOCIATION 


\title{
The Modern Language Association of America ORGANIZED 1883 INCORPORATED 1900
}

\author{
OFFICERS FOR THE YEAR 1971
}

President: Lous KAMPF, Massachusetts Institute of Technology

First Vice President: STUART ATKINS, University of California, Santa Barbara

Second Vice President: Florence Howe, State Univ. of New York, Old Westbury

Executive Secretary: William David Schaefer

Treasurer and Deputy Executive Secretary: KenNeTH W. Mildenberger

\section{EXECUTIVE COUNCIL}

For the term ending 31 December 1971

O. B. Hardison, Folger Shakespeare Library

Frank G. RYder, Indiana Univ.

W. FreEMan TWAdDEl, Brown Univ.

For the term ending 31 December 1972

REnE GIRARD, State Univ. of New York, Buffalo

Jean Hagstrum, Northwestern Univ.

Francis Lee Utley, Ohio State Univ.
For the term ending 31 December 1973

J. Hillis Miller, Johns Hopkins Univ. WALTER B. RideOUT, Univ. of Wisconsin PaUl Schach, Univ. of Nebraska

For the term ending 31 December 1974

Claudio Guillén, Univ. of California, San Diego

Margaret McKenzie, Vassar Coll.

Roberta SALPER, State Univ. of New York, Old Westbury

\section{TRUSTEES OF INVESTED FUNDS}

\author{
GoRDON N. RAY, Guggenheim Foundation, \\ Managing Trustee
}

C. Waller Barrett, Charlottesuille, Va. Frederick BurkhardT, American Council of Learned Societies

$P M L A$ is issued six times a year, in January, March, May, September, October, and November, by the Modern Language Association of America, 62 Fifth Avenue, New York, New York 10011. Annual dues for membership in the Association, which includes subscription to PMLA, are $\$ 25$ except for the following special categories: (a) student membership at $\$ 7$, open for a maximum of four years to those who are engaged primarily in a course of study leading to a degree and who do not hold full-time teaching appointments; (b) joint husbandand-wife membership at $\$ 35$ with only one subscription to $P M L A$; (c) foreign membership at $\$ 18$, open to resident citizens of countries other than the United States and Canada.

The subscription price of $P M L A$ for libraries and other institutions is $\$ 20$. Agents deduct $\$ 2$ as their fee. A subscription including a bound volume at the end of the year is $\$ 35$, domestic and foreign. Single copies of the January, March, May, October, and November Program issues may be obtained for $\$ 5$ each; the September Directory for $\$ 6$.

Issues for the current year are available from the MLA Materials Center. Claims for undelivered issues will be honored if they are received within one year of the publication date; thereafter the single issue price will be charged.

For information about the availability of back issues, inquire of Kraus Reprint Co., 16 East 46th St., New York 10017. Early and current volumes may be obtained on microfilm from University Microfilms, Ann Arbor, Mich. 48106. Purchase of current volumes on film is restricted to subscribers of the journal.

\section{OFFICE OF PUBLICATION AND EDITORIAL OFFICES \\ 62 Fifth Avenue, New York, N. Y. 10011 Tel.: 212 691-3200}

All communications, including notices of changes of address, should be sent to the Membership Office of the Association at 62 Fifth Avenue, New York 10011. If a change of address also involves a change of institutional affiliation, the Membership Office should be informed of this fact at the same time.

Second-class postage paid at New York, N. Y., and at additional mailing office.

Copyright (c) 1971 by The Modern Language Association of America.

Library of Congress Catalog Card Number 12-32040. 


\section{Contents $\cdot$ September}

Presidents of the Association, 1884-1971 . . . . . . . . . . . . . . 56I

Members of the Executive Council, 1950-71 . . . . . . . . . . . 562

Committees of the Association, 1950-71 . . . . . . . . . . . . . 564

Headquarters Staff of the Association. . . . . . . . . . . . 576

MLA Statistics . . . . . . . . . . . . . . . . . . . . . 578

Distribution of MLA Members. . . . . . . . . . . . . . 579

The MLA Bibliographical System: Past, Present, and Future. Harrison T. MESEROLE . . . . . . . . . . . . . . . . . . . . 580

A Few Missing Words. Matthew J. Bruccoli . . . . . . . . $\quad 587$

Physical Access to Library Materials. Gordon R. Williams . . . . . 590

Additions and Corrections, 1970 Program (November 1970 issue of PMLA) . 594

The 1970 Business Meeting

Actions . . . . . . . . . . . . . . . . . . . . 595

Summary of Discussion . . . . . . . . . . . . . . . . 599

Report of the Midwest Modern Language Association. Carl H. Klaus . . 601

Report of the Philological Association of the Pacific Coast. R. S. MeyersteIN 604

Report of the South Atlantic Modern Language Association. EDwARD W.

BratTon . . . . . . . . . . . . . . . . . . . . . 608

Report of the South Central Modern Language Association. JAmeS A. CASTAÑEdA . . . . . . . . . . . . . . . . 6I2

Report of the Rocky Mountain Modern Language Association. JAMES K. FOLSOM

616

Constitution and Bylaws of the Modern Language Association of America as Revised in December 1970 . . . . . . . . . . . . . . . . 619

Proposed Amendments to MLA Bylaws . . . . . . . . . . . 627

A Schedule of Deadlines in Connection with the Implementation of Constitutional Provisions . . . . . . . . . . . . . . . . . . 629

List of Honorary Members . . . . . . . . . . . . . . . 630

List of Honorary Fellows . . . . . . . . . . . . . . . 63I

List of Members . . . . . . . . . . . . . . . . . . 632

Necrology . . . . . . . . . . . . . . . . . . . 787

English and Foreign Language Department Chairmen, 1971-72
Four-Year Colleges and Universities

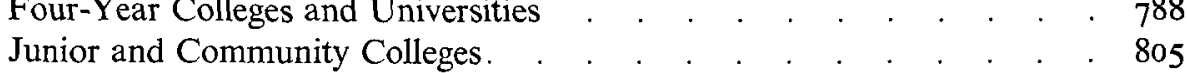

Chairmen and Directors of Ethnic Studies Programs . . . . . . . 814

Chairmen of Language and Area Programs . . . . . . . . . . 815

A Finding List for PMLA and the MLA Newsletter. . . . . . . . . 817

Fellowships and Grants . . . . . . . . . . . . . . . . 825

Forthcoming Meetings and Conferences of General Interest . . . . . . 834

Nominations for Second Vice President . . . . . . . . . . . 836

Professional Notes and Comment . . . . . . . . . . . . . . 836

Nominations to the Executive Council . . . . . . . . . . . . 837

Directory of Useful Addresses, 1971-72 . . . . . . . . . . . . . . . . 902 


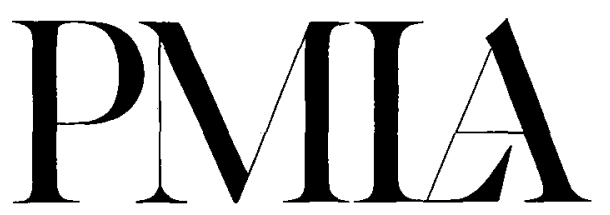

PUBLICATIONS OF THE MODERN LANGUAGE ASSOCIATION OF AMERICA

Published Six Times a Year

Indices: Vols. 1-50, 1935;51-60, 1945; 51-79, 1964

EDITORIAL COMMITTEE

David M. Bevington, 1974

University of Chicago

A. Dwight Culler, 1974

Yale University

Hugh M. Davidson, 1973

Ohio State University

RichaRd EllmanN, 1973

Oxford University

VICTOR ERLICH, 1974

Yale University

Donald J. GreENE, 1973

University of Southern California

Stanley B. Greenfield, 1975

University of Oregon

CECIL Y. LANG, 1973

University of Virginia

JAMES E. MILLER, JR., 1973

University of Chicago

Editor: William DAVID SCHAEFER

Editorial Assistant: JUDY GouldING
J. Mitchell MoRSe, 1974

Temple University

William G. Moulton, 1975

Princeton University

STEPHEN G. Nichols, JR., 1974

Dartmouth College

GEORGE NORDMEYER, 1972

Hunter College

PAUl R. Olson, 1974

Johns Hopkins University

EARL R. WASSERMAN, 1975

Johns Hopkins University

KaTHLEEN WiLliams, 1975

University of California, Riverside

Nathalia WRIGHT, 1975

University of Tennessee

ThEODORE J. ZIOLKOWSKI, 1975

Princeton University

Managing Editor: William PeLL

Advertising Coordinator: JudiTh FeLdMAN

\section{A STATEMENT OF EDITORIAL POLICY}

$P M L A$ endeavors to present distinguished contemporary scholarship and criticism in all fields of the modern languages and literatures. The distribution of papers should reflect the work actually being done from year to year, regardless of periods or languages. Members who feel their interests neglected by this policy are urged to write and to encourage others to write publishable articles.

$P M L A$ welcomes either new or traditional approaches by either young or established scholars. It urges authors to bear in mind that their audience is the entire membership of the Association and to strive to communicate the broader implications as well as the precise substance of their research. Articles should be written in a clear, concise, and attractive style, with documentation held to a minimum. $P M L A$ does not encourage notes or long articles; it does not review books.

Any member of the Association may submit papers to $P M L A$. Each paper submitted will be sent to at least one consultant reader and one member of the Editorial Committee. An abstract in English on the standard form must accompany every article submitted. Abstract forms and guidelines may be obtained from the Editor.

Manuscripts, prepared in conformity with the second edition of the MLA Style Sheet, should be addressed to the Editor of PMLA, 62 Fifth Avenue, New York, N. Y. 10011. Copies are not needed, but should be made and retained by the author. Pamphlets On the Publication of Research and on The Publication of Academic Writing may be purchased from the MLA Materials Center. 